\title{
Klasifikasi Genre Manga Menggunakan Convolutional Neural Network
}

\author{
Reynaldo Stefanus Hartono ${ }^{1}$, Hendrawan Armanto ${ }^{2}$ \\ ${ }^{1,2}$ Institut Sains dan Teknologi Terpadu Surabaya; Jl. Ngagel Jaya Tengah No.73-77, Baratajaya, \\ Kec. Gubeng, Kota SBY, Jawa Timur 60284, Telepon 0821-2290-7788 \\ Jurusan S2 Teknologi Informasi, Fakultas Sains dan Teknologi, Surabaya \\ e-mail: ${ }^{1}$ reynaldostefanushartono@gmail.com, ${ }^{2}$ hendrawan@stts.edu
}

\begin{abstract}
Abstrak
Peneliti melakukan percobaan tentang klasifikasi genre manga berdasarkan input berupa gambar hitam putih dan cover manga. Menentukan genre manga merupakan hal yang cukup menantang karena genre adalah fitur yang tidak terlihat secara fisik dalam manga, sehingga model deteksi gambar yang tersedia tidak dapat disesuaikan dengan mudah ke dalam konteks ini. Selain itu, multi-label classification lebih menantang dari binary classification ataupun multi-class classification mengingat satu input dapat ditetapkan ke beberapa kelas sekaligus [1]. Convolutional Neural Network merupakan metode yang sering digunakan untuk melakukan klasifikasi gambar karena mampu mendeteksi fitur utama gambar, kombinasi lapisan arsitekturnya mampu menghasilkan prediksi yang kompleks dan relevan [2][3]. Percobaan dilakukan melalui dua tahapan. Tahap pertama berisi 15 percobaan dengan struktur model convolutional neural network yang sama. Tahap kedua berisi 24 percobaan dengan mengubah struktur model convolutional neural networknya. Hasil terbaik yang diperoleh adalah percobaan ke-38 dengan akurasi 46.3 persen dan jumlah F1 yang aktif adalah 25 genre. Selain itu, peneliti telah menganalisa beberapa faktor yang mempengaruhi hasil penelitian yang telah diperoleh dengan harapan bisa berguna untuk peneliti lain yang ingin melakukan penelitian sejenis.
\end{abstract}

Kata kunci-Klasifikasi genre manga, Convolutional Neural Network, Multi-label classification

\begin{abstract}
Researcher conducted experiments about manga genre classification based on input in the form of black and white image and manga cover. Assigning genres to manga is a particularly challenging task because genre is a feature that is not physically present in a movie frame, so off-the-shelf image detection models cannot be easily adapted to this context. Moreover, multi-label classification is more challenging than binary classification or multiclass classification considering that one instance can be assigned to multiple class at once [1]. Convolutional Neural Network is a method that is often used to classify images because it is able to detect the main features of an image, the combination of architectural layers is able to produce complex and relevant predictions [2][3]. The experiment was carried out in two stages. The first stage contains 15 experiments with the same convolutional neural network model structure. The second stage contains 24 experiments by changing the structure of the convolutional neural network model. The best result obtained was the 38th trial with an accuracy of 46.3 percent and the number of active F1s was 25 genres. In addition, researchers have analyzed several factors that affect the results of the research that have been obtained in the hope that it will be useful for other researchers who want to carry out similar research.
\end{abstract}


Keywords-Manga genre classification, Convolutional Neural Network, Multi-label classification

\section{PENDAHULUAN}

$\mathrm{M}$ anga adalah sejenis komik yang berasal dari Jepang yang saat ini sangat populer di dunia [4]. Di Jepang sendiri, orang-orang dari segala kelompok usia senang membaca manga. Manga mencakup karya-karya berbagai genre, mulai dari action, comedy, romance, fantasy, dan berbagai genre menarik lainnya. Sudah banyak manga yang diterjemahkan ke bahasa lainnya, termasuk bahasa Indonesia dan Inggris sehingga budaya membaca manga di Indonesia bisa berkembang dengan cepat [5].

Perkembangan kebiasaan membaca manga menyebabkan kaum milenial Indonesia memiliki favoritas dari manga yang dibaca. Manga favorit seorang pembaca memiliki genre tertentu dan dalam sebuah manga pasti terdiri dari beberapa unsur genre. Genre akan menjadi gambaran unsur cerita yang terkandung di dalam sebuah manga. Berbeda dengan gambar cover maupun sinopsis, genre bisa lebih menggambarkan unsur cerita yang terkandung dalam sebuah manga.

Genre manga bisa bermacam-macam mulai dari Action, Comedy, Drama, Romance, School life, dan lain sebagainya. Action bisa menggambarkan isi cerita yang dimana ada pertarungan/tembak-tembakan/pengejaran. Comedy menggambarkan isi cerita yang lucu dan bisa membuat pembaca senang. School life dimana sebagian besar isi ceritanya menggambarkan sisi murid atau seorang remaja yang berada di sekolah [6].

Berdasarkan manga favorit yang pernah dibaca, akan timbul keinginan pembaca untuk menemukan genre cerita dari manga terbaru yang akan direlease musim berikutnya atau beberapa tahun kedepan. Manga yang akan direlease beberapa tahun kedepan biasanya sudah ada introduksi cerita maupun posternya, namun pembaca belum tahu tentang unsur cerita yang ada di dalamnya. Klasifikasi genre akan menghasilkan genre-genre dari beberapa manga yang ingin diprediksi berdasarkan gambarnya, hasilnya akan bisa memberikan gambaran kepada pembaca apakah suatu cerita isinya penuh aksi/sedih/lucu.

\section{METODE PENELITIAN}

Berikut ini akan dijelaskan metode yang akan digunakan untuk mengklasifikasikan genre manga kepada pembaca.

- Mengumpulkan data penelitian berupa gambar-gambar dalam suatu halaman manga yang akan digunakan untuk training dan testing. Folder training berisi gambar-gambar yang akan digunakan untuk proses training. Folder testing berisi gambar-gambar yang akan digunakan untuk proses pengecekan seberapa besar persentase ketepatan tebakan dari proses training. Folder testing nantinya akan dipecah menjadi 3 subfolder yang berisi gambar berwana, hitam putih, dan campuran.

- Melakukan preprocessing terlebih dahulu dengan mensegmentasi gambar dan menghapus teks yang ada di dalamnya. Preprocessing akan dilakukan beberapa kali karena hasil preprocessing akan menghasilkan jumlah data yang berbeda sehingga kemungkinan akan mempengaruhi hasil akhir prediksi genre manga

- Menyusun jaringan neural network menggunakan Jupyter Notebook yang akan digunakan untuk training dan testing [7]. Melakukan training terhadap gambar-gambar yang telah dikumpulkan sehingga bisa menghasilkan neural network yang baik. Melakukan testing terhadap gambar campuran, hitam putih, dan warna yang hasilnya disimpan dalam bentuk 
word. Langkah ini akan diulang terus menerus sehingga bisa memperoleh hasil akhir prediksi terbaik yang bisa diperoleh peneliti.

- Menganalisa hasil penelitian sehingga bisa menemukan beberapa faktor yang mempengaruhi hasil akhir penelitian. Menulis hasil penelitian dan analisanya ke dalam sebuah buku tesis.

\subsection{Arsitektur Dasar}

Arsitektur dasar akan menjelaskan alur penelitian dari awal hingga akhir. Penjelasan akan dilakukan dalam bentuk sederhana menggunakan gambar untuk mendeskripsikan langkah yang diperlukan untuk memperoleh hasil akhir penelitian.

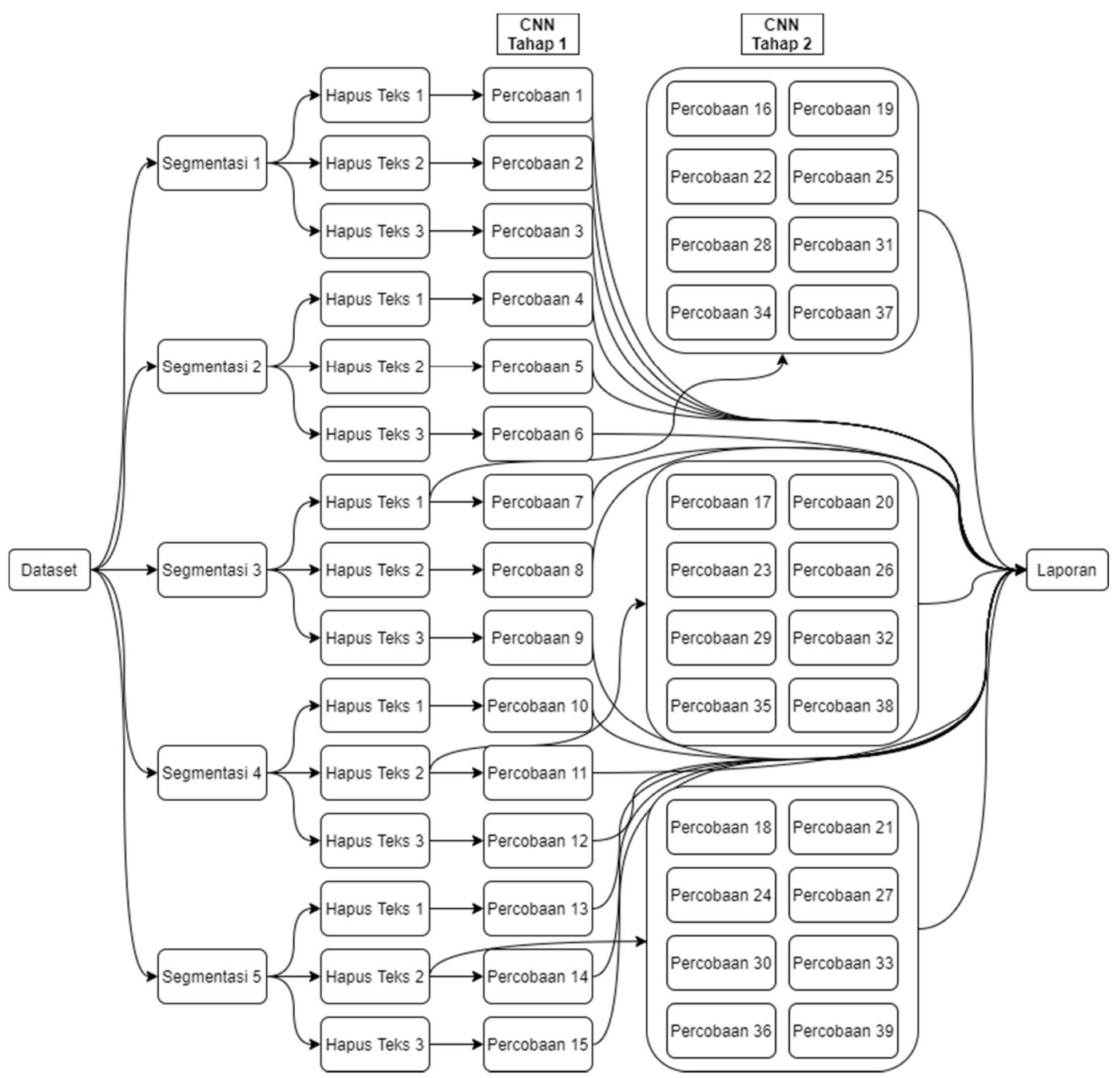

Gambar 1. Arsitektur Dasar

Gambar 1 merupakan arsitektur yang menjelaskan langkah yang dilakukan dari awal penelitian hingga akhir penelitian. Pada awalnya peneliti mengumpulkan dataset. Dataset berupa 2 hal yaitu file gambar dan file excel untuk mencatat nama gambar dan genrenya. Dataset yang dikumpulkan berupa dataset training yang memiliki total 10.000 data. Dataset testing campuran, testing hitam putih, dan testing warna memiliki total 9.000 data.

Setelah dataset siap, peneliti akan melakukan preprocessing segmentasi. Gambar akan dipotong untuk mengambil panel yang ada di dalamnya. Segmentasi akan dilakukan sebanyak 
lima kali sehingga bisa menghasilkan sampel data yang berbeda. Perbedaan setiap segmentasi terletak pada parameter filter yang digunakan.

Langkah selanjutnya adalah melakukan preprocessing penghapusan teks. Gambar yang telah tersegmentasi akan diproses lebih lanjut dengan menghapus teks yang ada di dalamnya. Penghapusan teks dilakukan sebanyak tiga kali untuk setiap hasil segmentasi sehingga menghasilkan lima belas sampel gambar berbeda untuk percobaan convolutional neural network yang akan dilakukan. Perbedaan setiap penghapusan teks terletak pada parameter resize untuk mengubah ukuran gambarnya menjadi kelipatan 32 pixel. Hal ini dilakukan sehingga program bisa berjalan dengan baik sesuai peraturan yang disarankan EAST detection [8].

Percobaan akan dilakukan melalui dua tahapan. Tahap pertama berisi 15 percobaan dengan struktur model convolutional neural network yang sama. Tahap kedua berisi 24 percobaan dengan mengubah struktur model convolutional neural networknya. Total keseluruhan percobaan yang dilakukan adalah 39 percobaan. Contoh percobaan tahap pertama dilakukan sesuai dengan gambar yang ada, percobaan pertama menggunakan data excel hasil segmentasi pertama dan data gambar hasil penghapusan teks pertama, percobaan kedua menggunakan data excel hasil segmentasi pertama dan data gambar hasil penghapusan teks kedua, dan cara yang sama dilakukan hingga percobaan ke 15. Contoh percobaan tahap kedua dilakukan sesuai gambar yang ada, percobaan keenam belas menggunakan dataset seperti percobaan ketujuh yaitu data excel hasil segmentasi ketiga dan data gambar hasil penghapusan teks pertama, cara yang sama dilakukan hingga percobaan ke 39 sesuai gambar yang ada. Outputnya berupa laporan yang menunjukkan akurasinya.

\subsection{Dataset}

Dataset penelitian akan diambil secara online dimana data hitam putih akan diambil dari website manga (mangabat.com) dan data cover/warna akan diambil dari website tersebut maupun halaman gambar pada google.com. Dataset penelitian dibagi menjadi 2, dataset training dan dataset testing. Dataset training berjumlah 10.000 data. Dataset testing berjumlah 9.000 data yang akan dibagi kedalam 3 buah folder yaitu campuran, hitam putih, dan warna. Genre yang digunakan sebagai hasil target penelitian berjumlah 25 genre yaitu Action, Adventure, Comedy, Cooking, Drama, Ecchi, Fantasy, Harem, Historical, Horror, Isekai, Josei, Martial Arts, Mecha, Mystery, Romance, School Life, Sci Fi, Seinen, Shoujo, Shounen, Slice of Life, Sports, Supernatural, Tragedy.

\subsection{Preprocessing}

Preprocessing yang akan dilakukan dibagi ke dalam dua langkah yaitu segmentasi gambar dan menghapus huruf. Di dalam suatu halaman manga yang diambil terdapat banyak panel yang berisi gambar-gambar, segmentasi bertujuan untuk mengambil panel-panel yang ada pada suatu halaman gambar. Setelah panel berhasil disegmentasi, langkah selanjutnya adalah menghapus huruf yang ada di dalam panel tersebut.

\subsubsection{Preprocessing Segmentasi}

Preprocessing segmentasi dilakukan sebanyak lima kali dengan filter yang berbeda-beda. Fungsi utama filter untuk meloloskan gambar yang ukurannya lebih besar sama dengan parameter filter. Gambar yang diambil selalu dengan ukuran segi empat, hal ini dilakukan karena yang diproses adalah gambar hitam putih dan berwarna, fungsi utama segmentasi adalah memotong panel yang ada pada gambar hitam putih, sementara gambar berwarna diharapkan untuk tidak terpotong. 
Tabel 1. Preprocessing Segmentasi

\begin{tabular}{|c|c|}
\hline Segmentasi & Filter \\
\hline Segmentasi 1 & 50 px dan $150 \mathrm{px}$ \\
\hline Segmentasi 2 & $175 \mathrm{px}$ dan $175 \mathrm{px}$ \\
\hline Segmentasi 3 & $15 \%$ dan $15 \%$ \\
\hline Segmentasi 4 & $20 \%$ dan $20 \%$ \\
\hline Segmentasi 5 & $25 \%$ dan $25 \%$ \\
\hline
\end{tabular}

Tabel 1 merupakan filter yang digunakan untuk memperoleh keseluruhan hasil segmentasi yang diinginkan peneliti. Proses segmentasi dilakukan sebanyak lima kali dengan hasil yang berbeda untuk setiap prosesnya. Filter yang digunakan pada segmentasi pertama adalah 50 pixel dan 150 pixel dimana pada proses pertama panel yang lolos filter dengan ukuran width dan height 50 pixel akan dilanjutkan ke proses kedua untuk mengambil panel yang ukuran width dan heightnya 150 pixel, segmentasi selanjutnya juga menggunakan proses yang sama. Filter yang digunakan pada segmentasi kedua adalah 175 pixel dan 175 pixel. Filter yang digunakan pada segmentasi ketiga adalah $15 \%$, hal ini menandakan bahwa segmentasi akan mengambil area segi empat yang ukuran width dan heightnya lebih besar sama dengan $15 \%$ ukuran original gambar. Filter yang digunakan pada segmentasi keempat adalah $20 \%$, hal ini menandakan bahwa segmentasi akan mengambil area segi empat yang ukuran width dan heightnya lebih besar sama dengan $20 \%$ ukuran original gambar. Filter yang digunakan pada segmentasi kelima adalah 25\%, hal ini menandakan bahwa segmentasi akan mengambil area segi empat yang ukuran width dan heightnya lebih besar sama dengan $25 \%$ ukuran original gambar.

\subsubsection{Preprocessing Hapus Teks}

Preprocessing hapus teks dilakukan sebanyak tiga kali untuk setiap hasil segmentasi dengan resize yang berbeda-beda. Fungsi utama resize untuk mengubah ukuran gambar dengan dimensi kelipatan 32 pixel untuk mengikuti peraturan yang digunakan pada EAST detector. EAST adalah singkatan dari Easy and Accurate Scene Text detection dimana fungsi utamanya adalah menemukan area teks pada suatu gambar.

Tabel 2. Preprocessing Hapus Teks

\begin{tabular}{|c|c|c|}
\hline Segmentasi & Hapus Teks & Resize \\
\hline \multirow{3}{*}{ Segmentasi 1 } & 1 & $576 \mathrm{px}$ \\
\cline { 2 - 3 } & 2 & $800 \mathrm{px}$ \\
\cline { 2 - 3 } & 3 & $1024 \mathrm{px}$ \\
\hline \multirow{3}{*}{ Segmentasi 2} & 4 & $576 \mathrm{px}$ \\
\cline { 2 - 3 } & 5 & $800 \mathrm{px}$ \\
\cline { 2 - 3 } & 6 & $1024 \mathrm{px}$ \\
\hline \multirow{3}{*}{ Segmentasi 3} & 7 & $576 \mathrm{px}$ \\
\cline { 2 - 3 } & 9 & $800 \mathrm{px}$ \\
\hline \multirow{3}{*}{ Segmentasi 4} & $1024 \mathrm{px}$ \\
\cline { 2 - 3 } & 11 & $576 \mathrm{px}$ \\
\cline { 2 - 3 } & 12 & $800 \mathrm{px}$ \\
\hline \multirow{3}{*}{ Segmentasi 5} & 13 & $576 \mathrm{px}$ \\
\cline { 2 - 3 } & 14 & $800 \mathrm{px}$ \\
\cline { 2 - 3 } & 15 & $1024 \mathrm{px}$ \\
\hline
\end{tabular}


Tabel 2 merupakan perubahan ukuran gambar yang dibutuhkan untuk memperoleh keseluruhan hasil preprocessing hapus teks yang diingingkan peneliti. Proses hapus teks dilakukan sebanyak lima belas kali. Setiap sample hasil segmentasi akan dipreprocessing hapus teks sebanyak tiga kali sehingga menghasilkan data yang berbeda. Ukuran perubahan width dan height yang digunakan adalah 576 pixel, 800 pixel, dan 1024 pixel.

\subsection{Convolutional Neural Network}

Jaringan neural network yang dibuat akan menggunakan library keras [9]. Keras menyediakan interface yang mudah untuk membangun jaringan neural network dan melakukan training kepada jaringan neural network yang dibuat, dengan menyembunyikan sebagian besar detail proses yang rumit untuk ditangani dan memungkinkan pembuat untuk fokus kepada jaringan neural networknya [10].

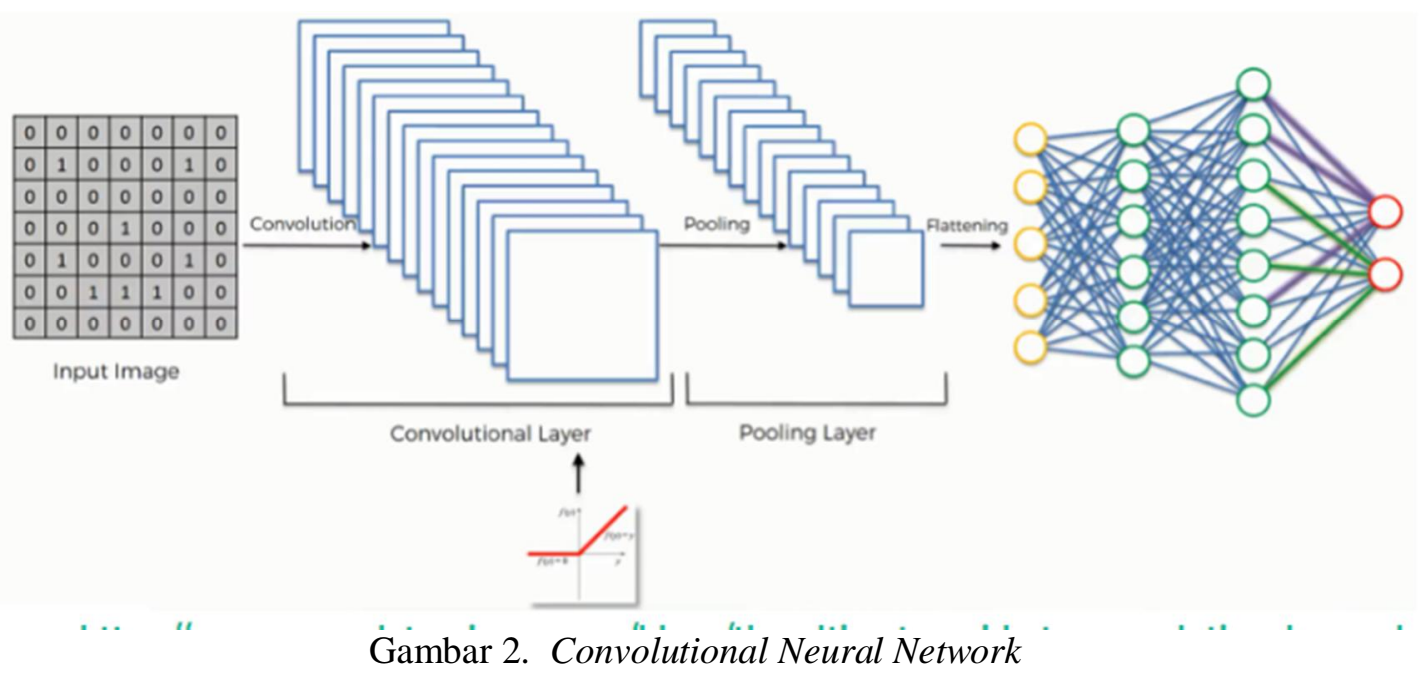

Gambar 2 menjelaskan proses yang umumnya ada pada neural network. Berikut ini adalah beberapa penjelasan proses tersebut

- Convolutional Layer, berguna untuk mengubah dimensi gambar sehingga memory neural network bisa cukup untuk banyak data

- Pooling Layer, berguna untuk memperbaiki dimensi yang dihasilkan convolutional layer dengan mengambil nilai terbaik yang dibutuhkan

- Fully Connected Layer, berguna untuk menghasilkan probabilitas untuk setiap kelas, probabilitas yang dihasilkan akan tergantung kepada bobot yang diatribusikan kepada tiap neuran di klasifikasi akhir. Melalui backpropagation, Keras akan secara otomatis menyesuaikan bobot masing-masing koneksi untuk meminimalkan kesalahan klasifikasi.

\section{HASIL DAN PEMBAHASAN}

Pada bagian ini akan dijelaskan dua hal yakni hasil uji coba dan pembahasan. Hasil uji coba akan menjelaskan hasil yang diperoleh dari hasil preprocessing hingga hasil akhir penelitian. Pembahasan akan mendiskusikan atau menganalisa berbagai hal yang dialami selama penlitian sehingga bisa berguna untuk peneliti lain yang ingin melakukan penelitian sejenis. 


\subsection{Hasil Uji Coba}

Pada bagian ini akan dijelaskan hasil yang diperoleh selama preprocessing hingga hasil akhir penelitian. Hasil preprocessing dibagi menjadi hasil segmentasi dan hasil penghapusan teks. Hasil akhir penelitian merupakan laporan yang diperoleh setelah training dan testing pada convolutional neural network.

\subsubsection{Hasil Uji Coba Segmentasi}

Preprocessing segmentasi dilakukan sebanyak lima kali dengan filter yang berbeda-beda. Fungsi utama filter untuk meloloskan gambar yang ukurannya lebih besar sama dengan parameter filter. Gambar yang diambil selalu dengan ukuran segi empat, hal ini dilakukan karena yang diproses adalah gambar hitam putih dan berwarna, fungsi utama segmentasi adalah memotong panel yang ada pada gambar hitam putih, sementara gambar berwarna diharapkan untuk tidak terpotong.

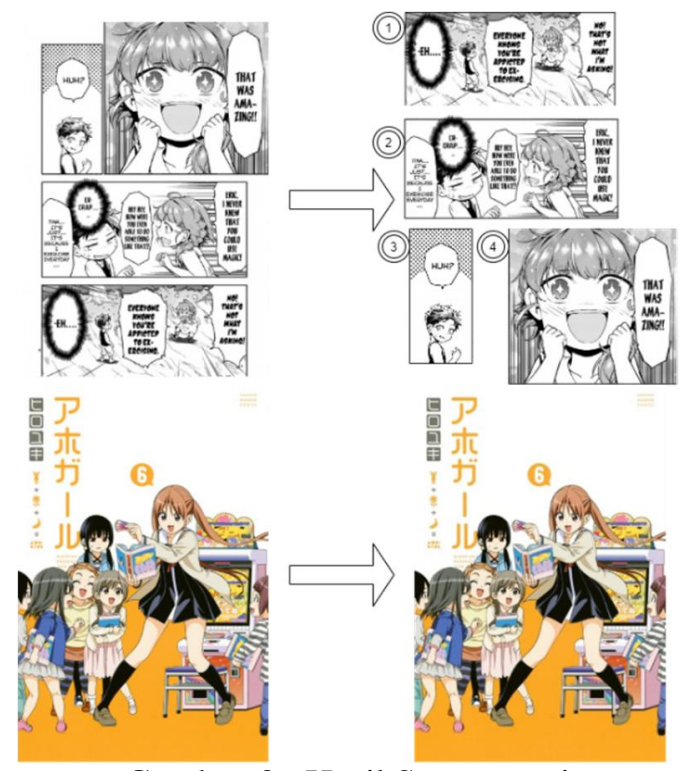

Gambar 3. Hasil Segmentasi

Gambar 3 merupakan contoh hasil segmentasi yang baik. Segmentasi dilakukan pada gambar hitam putih dan berwarna. Segmentasi pada gambar hitam putih yang baik adalah berhasil memotong panel-panel yang ada pada gambar. Segmentasi pada gambar berwarna yang baik adalah gambar tersebut tidak terpotong sama sekali karena gambar berwarna yang digunakan merupakan gambar cover sehingga sifatnya utuh. Tidak semua proses segmentasi menghasilkan potongan gambar yang diinginkan karena keberagaman gambar yang ada.

\subsubsection{Hasil Uji Coba Hapus Teks}

Preprocessing hapus teks dilakukan sebanyak tiga kali untuk setiap hasil segmentasi dengan resize yang berbeda-beda. Fungsi utama resize untuk mengubah ukuran gambar dengan dimensi kelipatan 32 pixel untuk mengikuti peraturan yang digunakan pada EAST detector. EAST adalah singkatan dari Easy and Accurate Scene Text detection dimana fungsi utamanya adalah menemukan area teks pada suatu gambar. 


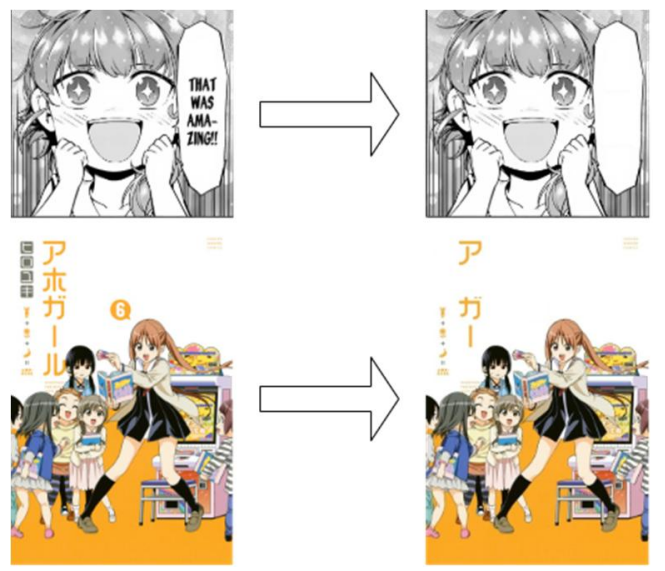

Gambar 4. Hasil Hapus Teks

Gambar 4 merupakan contoh hasil preprocessing hapus teks yang baik. Preprocessing hapus teks dilakukan pada seluruh gambar yang telah tersegmentasi. Hapus teks dikatakan baik jika seluruh teks yang ada pada gambar berhasil terhapus. Pada contoh gambar hitam putih seluruh teks berhasil dihapus dan area lainnya tidak ada yang ikut rusak karena terhapus. Pada contoh gambar berwarna beberapa teksnya terhapus sehingga bisa dikatakan baik dan area lainnya tidak ada yang rusak karena terhapus.

\subsubsection{Hasil Convolutional Neural Network}

Uji coba Convolutional Neural Network dibagi menjadi 2 tahapan. Total percobaan yang dilakukan adalah 39 percobaan. Pada tahap pertama dilakukan 15 percobaan. Pada tahap kedua dilakukan 24 percobaan. Hasil akhir yang akan dilihat pada setiap tahap percobaan adalah akurasi keseluruhan dan active F1 score setiap genre.

\subsubsection{Tahap Pertama}

Pada tahap pertama dilakukan 15 percobaan. Setiap percobaan yang dilakukan memiliki struktur convolutional neural network yang sama, namun data yang digunakan berbeda-beda. Dataset yang digunakan adalah 15 data hasil preprocessing. Tujuan tahap pertama adalah menentukan data yang akan digunakan untuk penelitian tahap kedua berdasarkan akurasi keseluruhan dan active F1 score setiap genre.

Tabel 3. Tahap Pertama

\begin{tabular}{|c|c|c|c|c|}
\hline Percobaan & Total Genre & Prediksi Benar & Akurasi & Active F1 \\
\hline 1 & 83639 & 44932 & 53.72 & 14 \\
\hline 2 & 83639 & 45051 & 53.86 & 15 \\
\hline 3 & 83639 & 45050 & 53.86 & 15 \\
\hline 4 & 82969 & 44685 & 53.86 & 15 \\
\hline 5 & 82969 & 44453 & 53.58 & 12 \\
\hline 6 & 82969 & 44684 & 53.86 & 15 \\
\hline 7 & 84655 & 45608 & 53.88 & 15 \\
\hline 8 & 84655 & 45179 & 53.37 & 12 \\
\hline 9 & 84655 & 45436 & 53.67 & 12 \\
\hline 10 & 77287 & 40908 & 52.93 & 16 \\
\hline 11 & 77287 & 41711 & 53.97 & 15 \\
\hline 12 & 77287 & 41467 & 53.65 & 14 \\
\hline 13 & 66208 & 35836 & 54.13 & 14 \\
\hline
\end{tabular}




\begin{tabular}{|l|l|l|l|l|}
\hline 14 & 66208 & 35831 & 54.12 & 15 \\
\hline 15 & 66208 & 35561 & 53.71 & 12 \\
\hline
\end{tabular}

Tabel 3 menunjukkan hasil uji coba tahap pertama. Percobaan terbaik dengan total genre yang sama adalah percobaan ke-2, percobaan ke-4, percobaan ke-7, percobaan ke-11, dan percobaan ke-14. Pada tahap selanjutnya, peneliti memilih untuk meneliti lebih lanjut data yang digunakan pada percobaan ke-7, percobaan ke-11, dan percobaan ke-14. Peneliti memilih data tersebut berdasarkan hasil akurasi dan active F1 yang ada. Dapat diambil kesimpulan bahwa preprocessing data tersebut lebih baik dibandingkan percobaan lainnya.

\subsubsection{Tahap Kedua}

Pada tahap kedua dilakukan 24 percobaan. Setiap percobaan yang dilakukan memiliki struktur convolutional neural network yang berbeda. Dataset yang digunakan adalah data hasil preprocessing ketujuh, kesebelas, dan keempat belas. Data ini dipilih karena berdasarkan akurasi keseluruhan dan rata-data F1 score setiap genrenya merupakan yang terbaik menurut peneliti. Tujuan tahap kedua adalah memperoleh hasil yang lebih baik dari percobaan tahap pertama berdasarkan akurasi keseluruhan dan rata-rata F1 score setiap genre.

Tabel 4. Tahap Kedua

\begin{tabular}{|c|c|c|c|c|}
\hline Percobaan & Total Genre & Prediksi Benar & Akurasi & Active F1 \\
\hline 16 & 84655 & 45487 & 53.73 & 16 \\
\hline 17 & 77287 & 41478 & 53.67 & 15 \\
\hline 18 & 66208 & 35755 & 54.0 & 13 \\
\hline 19 & 84655 & 45434 & 53.67 & 16 \\
\hline 20 & 77287 & 41838 & 54.13 & 14 \\
\hline 21 & 66208 & 35538 & 53.68 & 14 \\
\hline 22 & 84655 & 45807 & 54.11 & 16 \\
\hline 23 & 77287 & 41513 & 53.71 & 16 \\
\hline 24 & 66208 & 35705 & 53.93 & 14 \\
\hline 25 & 84655 & 43864 & 51.82 & 21 \\
\hline 26 & 77287 & 42170 & 54.56 & 18 \\
\hline 27 & 66208 & 36007 & 54.38 & 19 \\
\hline 28 & 84655 & 45156 & 53.34 & 21 \\
\hline 29 & 77287 & 41751 & 54.02 & 18 \\
\hline 30 & 66208 & 36101 & 54.53 & 16 \\
\hline 31 & 84655 & 44603 & 52.69 & 17 \\
\hline 32 & 77287 & 41956 & 54.29 & 15 \\
\hline 33 & 66208 & 35771 & 54.03 & 16 \\
\hline 34 & 84655 & 45136 & 53.32 & 21 \\
\hline 35 & 77287 & 41948 & 54.28 & 18 \\
\hline 36 & 66208 & 36083 & 54.5 & 18 \\
\hline 37 & 84655 & 37222 & 43.97 & 25 \\
\hline 38 & 77287 & 35786 & 46.3 & 25 \\
\hline 39 & 66208 & 35097 & 53.01 & 23 \\
\hline
\end{tabular}

Tabel 4 menunjukkan hasil uji coba tahap kedua. Percobaan terbaik adalah percobaan ke38 dengan akurasi 46.3 persen dan jumlah active F1 adalah 25 genre. Dari laporan percobaan yang ada bisa diambil kesimpulan bahwa tidak ada struktur neural network yang pasti benar sehingga perlu dilakukan banyak percobaan untuk memperoleh hasil yang lebih maksimal. 


\subsection{Pembahasan}

Pada bagian ini akan dilakukan pembahasan dengan menganalisa berbagai hal yang terjadi selama penelitian. Hal yang akan dibahas mencakup masalah-masalah yang mungkin muncul dan faktor yang mempengaruhi hasil penelitian. Dengan adanya pembahasan ini, diharapkan bisa berguna untuk peneliti lain yang ingin melakukan penelitian sejenis.

\subsubsection{Masalah yang Dialami Saat Penelitian}

Setelah melakukan beberapa percobaan, pasti akan muncul beberapa masalah yang akan dialami saat penelitian. Setiap masalah yang muncul harus diatasi untuk bisa menyelesaikan penelitian yang dilakukan. Berikut adalah masalah-masalah yang dialami saat percobaan:

- Data tidak boleh salah. Penamaan gambar dan excel harus tepat. Pengisian genre di excel harus benar.

- Waktu training cukup lama dan selama training pemakaian memory sangat tinggi sehingga tidak bisa melakukan aktivitas lainnya.

- Gambar bisa corrupt dan tidak bisa dibaca oleh python sehingga harus membenarkannya

- [Memory Error:] adalah masalah yang kadang muncul saat run training berulang-ulang pada file yang sama. Peneliti belum ditemukan cara mengatasinya sehingga harus menutup dan membuka ulang file.

- Menyimpan gambar yang banyak dengan resolusi original ke dalam sebuah array bisa menyebabkan dead kernel/outofmemory/forced closed browser

- ZeroDivision merupakan error yang akan ditemukan ketika pembagi yang ada bernilai nol, bisa diatasi dengan menggunakan if

- Pada saat penyusunan struktur model convolutional neural network, parameter yang ada bisa mempengaruhi dimensi gambar sehingga kemungkinan error ketika dimensi yang diproses tidak sesuai.

- Pada saat pembuatan laporan hasil percobaan, jika jumlahnya banyak, maka sebaiknya tidak ditampilkan pada file python, namun ditampilkan dengan cara export hasilnya dalam bentuk word atau pdf.

\subsubsection{Faktor yang Mempengaruji Hasil Penelitian}

Setelah melakukan beberapa percobaan, pasti akan muncul pertanyaan "Faktor apa saja yang mempengaruhi sehingga ada beberapa hasil F1 yang nol atau genrenya tidak terprediksi dengan baik?". Ada beberapa kemungkinan yang bisa menyebabkan hasil F1 nya kurang maksimal, berikut adalah beberapa kemungkinan yang menyebabkan hal tersebut:

- Jumlah genre yang ada pada data training dan data testing. Jika data yang dikumpulkan memiliki urutan data training dan data testing dari yang paling banyak hingga paling sedikit yang berbeda jauh, maka hasil prediksinya kemungkinan tidak akan bisa maksimal.

- Genre dengan gambar yang hampir mirip. Hal ini bisa menyebabkan genre yang datanya lebih banyak saat ditraining untuk memiliki probabilitas terprediksi yang lebih tinggi dibandingkan genre yang datanya lebih sedikit. Contohnya jika genre action memiliki data yang lebih banyak dari genre martial arts, dimana kedua genre tersebut memiliki gambar yang hampir mirip, maka kemungkinan probabilitas terprediksi genre martial arts akan ditekan oleh genre action.

- Model neural network yang dibuat kurang maksimal. Terdapat banyak parameter yang bisa diubah-ubah dan tidak ada nilai pasti yang akan menghasilkan hasil yang selalu baik. Contohnya dari percobaan yang ada, peneliti awalnya mengira bahwa percobaan menggunakan dataset ketujuh (percobaan 37) hasilnya merupakan yang terbaik karena pada beberapa percobaan sebelumnya akurasi dan active F1 yang dihasilkan lebih maksimal dari percobaan menggunakan dataset kesebelas maupun keempat belas. Namun, bisa dilihat 
pada percobaan 38, ternyata memang tidak ada hasil yang selalu pasti baik pada pembuatan struktur neural network, akurasi dan active F1 yang dihasilkan pada percobaan 38 yang menggunakan dataset kesebelas lebih baik dari percobaan 37 yang menggunakan dataset ketujuh. Padahal pada percobaan sebelum-sebelumnya, percobaan menggunakan dataset ketujuh hasilnya selalu lebih baik dari percobaan menggunakan dataset kesebelas.

- Jumlah target prediksi (dalam hal ini genre yang berjumlah 25), semakin banyak genrenya akan mempengaruhi F1 maupun akurasinya. Semakin banyak jumlah pilihan jawaban dan kombinasi jawaban, maka akan semakin tinggi tingkat kesulitan neural network untuk menebak jawaban yang tepat. Contohnya bisa dilihat dengan membandingkan percobaan ke 34 dan percobaan ke 37, pada percobaan ke 37, hasil active F1 lebih maksimal dari percobaan ke 34, namun akurasi percobaan ke 37 lebih rendah dari percobaan ke 34 karena jangkauan prediksi percobaan 37 lebih luas dari percobaan ke 34. Dari hal ini, bisa disimpulkan bahwa hasil percobaan ke 37 lebih maksimal dari percobaan ke 34 .

\section{KESIMPULAN} penelitian:

Pada bagian ini akan dibahas mengenai kesimpulan yang didapat setelah melakukan

- Berhasil melakukan penelitian dengan uji coba sebanyak 15 kali dengan data hasil preprocessing yang berbeda dan 24 kali dengan struktur convolutional neural network yang berbeda. Dari ke 39 percobaan, hasil yang paling maksimal adalah percobaan ke- 38 dengan akurasi 46.3 persen dan jumlah active F1 adalah 25 sehingga semua genrenya bisa diprediksi, hal ini lebih baik dari beberapa penelitian sebelumnya yang hanya memiliki jumlah active $\mathrm{F} 1$ yang lebih rendah dari 20.

- Dari laporan penelitian, berhasil diperoleh beberapa kesimpulan yang kemungkinan mempengaruhi nilai F1 genre maupun akurasi keseluruhannya, berikut adalah beberapa penyebabnya:

○ Jumlah genre yang ada pada data training dan data testing.

- Genre dengan gambar yang hampir mirip.

- Struktur model convolutional neural network yang dibuat kurang maksimal.

o Jumlah target prediksi (dalam hal ini genre yang berjumlah 25), semakin banyak genrenya akan mempengaruhi F1 maupun akurasinya.

\section{SARAN}

Bagian ini akan menjelaskan mengenai saran yang membangun dalam membuat program serta buku dokumentasi penelitian:

- Selalu melakukan pencatatan dari output yang muncul, pencatatan bisa meliputi error saat menjalankan program, waktu yang digunakan saat melakukan pengumpulan data atau preprocessing atau menjalankan training dan testing.

- Saat menggunakan jupyter notebook, detail memory yang digunakan sangat penting. Dianjurkan untuk menginstall nbresuse. Ekstensi ini ditujukan untuk mencatat memory pada bagian kanan atas file python. Terkadang seseorang lupa untuk melakukan shutdown terhadap file yang dijalankan sehingga penggunaan memorynya meningkat. Peningkatan penggunaan memory bisa menyebabkan proses yang ingin dijalankan melambat.

- Default file python jupyter notebook tidak menampilkan line number pada bagian kiri. Line number penting digunakan untuk mengatasi jika terjadi error pada line tertentu sehingga bisa 
mempercepat proses perbaikan error. Line number bisa ditampilkan dengan menekan bagian border cell code lalu menekan 1 (lowercase L).

\section{UCAPAN TERIMA KASIH}

Penulis mengucapkan terima kasih kepada bapak Hendrawan Armanto S.Kom., M.Kom yang telah memberi dukungan sebagai pembimbing dalam proses penelitian ini.

\section{DAFTAR PUSTAKA}

[1] Jesse Read and Fernando Perez-Cruz. 2014, Deep Learning for Multi-label Classification.

[2] Gabriel S. Simoes, Jonatas Wehrmann, Rodrigo C. Barros, and Duncan D. Ruiz. 2016, Movie Genre Classification with Convolutional Neural Networks, In Proceedings of International Joint Conference on Neural Networks.

[3] Wei-Ta Chu and Hung-Jui Guo. 2017, Movie Genre Classification based on Poster Images with Deep Neural Networks.

[4] Satsuki Murakami and Mio Bryce. 2009, Manga As An Educational Medium.

[5] Heike J. 2008, Translating Manga.

[6] Mio Bryce and Jason Davis. 2010, An Overview of Manga Genres, 34-61.

[7] Bernadette M. R., Irene V. P., Milena S. G., and Christine L.B. 2017, Using The Jupyter Notebook As A Tool for Open Science: An Empirical Study.

[8] Xinyu dkk., 2017, EAST: An Efficient and Accurate Scene Text Detector.

[9] Keyron O'Shea and Ryan Nash. 2015, An Introduction to Convolutional Neural Networks.

[10] Antonio Gulli and Sujit Pal. 2017, Deep Learning with Keras. 